\title{
PENGEMBANGAN BAHAN AJAR STRUKTUR ALJABAR BERBASIS PENDEKATAN DEDUKTIF UNTUK MENINGKATKAN HOT SKILL MAHASISWA UNIVERSITAS RIAU KEPULAUAN (UNRIKA) BATAM
}

\section{ALGEBRA STRUCTURES DEVELOPMENT BASED ON DEDUCTIVE APPROACH TO INCREASE STUDENTS' HOT SKILL AT UNIVERSITY RIAU KEPULAUAN (UNRIKA) BATAM}

\author{
${ }^{1}$ Nina Agustyaningrum, ${ }^{2}$ Yessy Yusnita \\ ${ }^{1,2}$ Program Studi Pendidikan Matematika, Fakultas Keguruan dan Ilmu Pendidikan, \\ Universitas Riau Kepulauan, Indonesia \\ Email::1agustyaningrum@gmail.com, ${ }^{2}$ yessyyusnita14@gmail.com
}

\begin{abstract}
Abstrak
Tujuan penelitian ini adalah: (1) Menghasilkan produk berupa bahan ajar berbentuk modul sruktur aljabar berbasis pendekatan deduktif yang valid dan praktis: (2) Mengetahui dampak bahan ajar struktur aljabar berbasis pendekatan deduktif dalam meningkatkan HOT skill mahasiswa Program Studi Pendidikan Matematika Universitas Riau Kepulauan (UNRIKA). Metode penelitian ini menggunakan model pengembangan 4D dari Thiagarajan yaitudefine (pendefinisian), design (perancangan), development (pengembangan), and dissemination (penyebarluasan). Data yang diperoleh terdiri dari data validitas melalui instrumen lembar angket validasi bahan ajar, praktikalitas melalui angket respon mahasiswa, dan efektifitas melalui tes keterampilan berfikir tingkat tinggi. Kriteria validitas, praktikalitas dan efektivitas ditentukan oleh peneliti. Dari penelitian yang telah dilaksanakan, diperoleh kesimpulan: (1) Bahan ajar berupa modul struktur aljabar bebasis pendekatan deduktif yang dihasilkan telah valid dan praktis dengan tingkat kevalidan sebesar $90.77 \%$ (katagori sangat baik) dan tingkat kepraktisan sebesar 79.85\% (kategori baik); (2) Dampak bahan ajar berupa modul modul struktur aljabar berbasis pendekatan deduktif yang dihasilkan belum cukup efektif dalam meningkatkan hinger order thingking skill (kemampuan berpikir tingkat tinggi) mahasiswa dengan perolehan skor rata-rata hasil tes kemampuan berpikir tingkat tinggi pada kelas eksperimen sebesar 62.46 dan kelas kontrol 60.53. Dari hasil uji statistik dengan uji U Mann Whitney diperoleh nilai signifikansi 0.31 lebih besar dari taraf signifikan0.05 sehingga dapat disimpulkan bahwa tidak terdapat perbedaan yang signifikan antara hasil tes kelompok eksperimen dan kontrol.
\end{abstract}

Kata Kunci : Bahan Ajar, Struktur Aljabar, Pendekatan Deduktif, HOT skill

\begin{abstract}
The study aim to: (1) produce product in the form of algebra structure teaching materials based on deductive approach that valid and practical; (2) Determine the impact of using algebra structure teaching materials based of deducative approach in improving student"s HOT Skills on Mathematics Education Depatment, University of Riau Kepulauan (UNRIKA) Batam. Methods this research using the development model of 4D Thiagarajan which stands for define, design, development, and dissemination. The data consisted of validity, practicalities, and the effectiveness through higher order thingking skills test. The criterion of validity, practicalities, and the effectiveness was determined by the researher. The result of research: (1) the teaching materials in the form of algebra structure modules that generated based on deductive approach was valid and practical with the level of validity was $90.77 \%$ (very good category) and the level of practicality was $79.85 \%$ (good category): (2) the impact of using the teaching materials in the form of algebra structure modules generated based deductive acquisition of the average score of the test result in the experimental class at 62.46 and the control class 60.53 . From the result of statistical test by Mann Withney $U$ test was obtained significance value of 0.31 was greater than the significance level of 0.05 so that it can be concluded that there was no significance different between the students test result of the experimental and control groups.
\end{abstract}

Keywords : teaching materials, algebra structure, deductive approach, HOT skill 


\section{PENDAHULUAN}

Mata kuliah struktur aljabar di Universitas Riau Kepulauan menjadi salah satu mata kuliah yang diwajibkan pada program studi pendidikan matematika.Mata kuliah ini terbagi menjadi dua yaitu struktur aljabar I yang diselenggarakan pada semester $\mathrm{V}$ dan struktur aljabar II pada semester VI.Ilmu aljabar menurut Sukirman (2005: ii) merupakan suatu studi yang berkenaan dengan himpunan dan operasi pada anggota himpunan tersebut. Oleh karena itu, aljabar memuat banyak struktur atau sistem sebagai materi yang harus dipelajari. Sementara itu, struktur aljabar merupakan salah satu cabang ilmu matematika yang memiliki konsep abstrak. Pada struktur aljabar I dipelajari tentang teori grup yaitu sifat-sifat suatu himpunan dengan satu operasi biner, sedangkan pada struktur aljabar II dipelajari tentang teori ring yang membahas sifat himpunan yang dilengkapi dengan dua operasi biner.

Mata kuliah struktur aljabar memiliki struktur deduktif aksiomatis yang sarat dengan konsep yang abstrak baik pada definisi maupun teorema atau aksiomanya.Sehingga mata kuliah ini sangat menuntut keterampilan mahasiswa dalam berpikir analisis dan bernalar yang menyangkut penyelesaian masalah maupun pembuktian teorema.Namun karena karakteristik materi yang abstrak, maka mata kuliah ini dirasa sulit oleh sebagian besar mahasiswa.Berdasarkan hasil observasi awal peneliti terhadap mahasiswa semester ganjil T.A. 2016/2017 yang tengah mengambil mata kuliah struktur aljabar I, sebagian besar mahasiswa menyatakan kesulitan dalam mengikuti perkuliahan struktur aljabar.Penyebabnya yang pertama adalah dikarenakan konsep yang abstrak dan sarat dengan pembuktian.Selanjutnya bahan ajar yang ada sebagian besar berbahasa Inggris sehingga mahasiswa kesulitan dalam mempelajarinya. Sebagian bahan ajar yang lain dirasa oleh mahasiswa sulit dipahami bahasanya. Hal ini mungkin dikarenakan buku sudah cetakan lama sehingga masih menggunakan tata Bahasa lama.padahal penggunaan bahan ajar sangat penting dalam mendukung proses perkuliahan seperti hasil penelitian yang dilaporkan oleh (Gusmania, 2010) bahwa penggunaan bahan ajar berupa modul geometri analitik ruang yang dikembangkan telah valid, praktis, dan efektif dalam meningkatkan kompetensi mahasiswa di Universitas Riau Kepulauan.

Melihat realitas tersebut, sangat perlu untuk dikembangkan sebuah bahan ajar yang valid, praktis, dan efektif untuk memudahkan mahasiswa dalam memahami materi yang selama ini dirasa sulit.Bahan ajar yang dikembangkan harus sesuai dengan kurikulum yang digunakan serta mempertimbangkan kebutuhan dan karakteristik mahasiswa.Salah satu pendekatan yang dapat digunakan sebagai basis dalam mengembangkan bahan ajar untuk 
membantu mahasiswa dalam memahami materi struktur aljbar adalah pendekatan deduktif.Karakteristik materi struktur aljabar yang abstrak dan sarat dengan pembuktian deduktif aksiomatis membuat pendekatan deduktif dirasa sesuai untuk mempermudah mahasiswa dalam belajar.

Pendekatan deduktif (deductive approach) adalah pendekatan yang menggunakan logika untuk menarik satu atau lebih kesimpulan berdasarkan seperangkat premis yang diberikan.Metode deduktif sering digambarkan sebagai pengambilan kesimpulan dari sesuatu yang umum ke sesuatu yang khusus.

Menurut Sagala (2010: 76) pendekatan deduktif ditandai dengan pemaparan konsep definisi dan istilah-istilah pada bagian awal pembelajaran. Pendekatan deduktif dilandasi oleh suatu pemikiran bahwa proses pembelajaran akan berlangsung dengan baik bila siswa telah mengetahui wilayah persoalannya dan konsep dasarnya. Selanjutnya, Chiappetta \& Koballa (2010: 133):

"The deductive approach is a vocabulary-before-experience model of teaching where lecture and discussion precede firsthand or concrete experience. It can also involve hypothetical-deductive thinking,whereby the learner generates ideas to be tested or discovered or the teacher makes explicit what is the students should be looking for in the laboratory or field."

Maksud dari pernyataan di atas, pendekatan deduktif merupakan suatu model penjelasan sebelum pengalaman belajar, di mana ceramah dan diskusi dilakukan lebih awal atau pengalaman konkret. Hal ini juga dapat melibatkan pemikiran hipotesis deduktif, di mana pebelajar menemukan ide-ide yang akan diuji atau ditemukan atau guru menjelaskan secara eksplisit apa yang harus dicari pebelajar di laboratorium atau lapangan. Dengan demikian, dapat disimpulkan bahwa pembelajaran dengan pendekatan deduktif dimulai dengan menyajikan aturan, teorema, atau prinsip umum yang diikuti dengan contoh-contoh khusus atau penerapan aturan, prinsip umum ke dalam keadaan khusus.

Selanjutnya berdasarkan pengalaman peneliti dalam mengampu mata kuliah struktur aljabar, mahasiswa masih kesulitan dalam mengembangkan kemampuan bernalarnya atau kemampuan berpikirnya pada level yang tinggi (higher order thinking skill). Padahal dalam mempelajari struktur aljabar sangat dituntut kemampuan berpikir tingkat tinggi ini. Menurut Tran Vui (2001:5) “Higher order thinking occurs when a person takes new information and information stored in memory and interrelates and/or rearranges and extends this information to achieve a purpose or find possible answers in perplexing situations”. Maksud dari pernyataan tersebut adalah kemampuan berpikir tingkat tinggi akan terjadi ketika 
seseorang mengaitkan informasi baru dengan informasi yang sudah tersimpan di dalam ingatannya dan menghubung-hubungkannya dan/atau menata ulang serta mengembangkan informasi tersebut untuk mencapai suatu tujuan ataupun menemukan suatu penyelesaian dari suatu keadaan yang sulit dipecahkan.

Menurut Krulik \& Rudnick (1999), secara umum keterampilan berpikir terdiri atas empat tingkat (level), yaitu menghafal (recall thinking), dasar (basic thinking), kritis (critical thinking) dan kreatif (creative thinking). Dua tingkatan berpikir yang terakhir yaitu berpikir kritis dan kreatif inilah yang kemudian disebut dengan keterampilan berpikir tingkat tinggi.Menurut Ennis(Rosnawati, 2009), berpikir kritis adalah cara berpikir reflektif yang masuk akal atau berdasarkan nalar yang difokuskan untuk menentukan apa yang harus diyakini dan dilakukan.Kemudian Angelo (Rosnawati, 2009) menegaskan bahwa berpikir kritis harus memenuhi karakteristik kegiatan berpikir yang meliputi analisis, sintesis, pengenalan masalah dan pemecahannya, kesimpulan, dan penilaian.Berpikir kritis merupakan salah satu jenis berpikir yang konvergen, yaitu menuju ke satu titik (kesimpulan).

Sedangkan kemampuan berpikir kreatif adalah kemampuan seseorang untuk menghasilkan komposisi, produk, atau gagasan apa saja yang pada dasarnya baru, dan sebelumnya tidak dikenali pembuatnya (Hurlock, 1978). Berpikir kreatif adalah jenis berpikir divergen, yang bersifat menyebar dari suatu titik.Dengan demikian perlu adanya kesinambungan antara berpikir kritis dan kreatif.

Kemampuan berpikir kritis dan kreatif ini juga cocok jika dikaitkan dengan taksonomi Bloom yang telah direvisi, yang menyatakan bahwa kemampuan berpikir tingkat tinggi meliputi kemampuan menganalisis, mengevaluasi, dan mencipta (Utari, 2017: 3). Menurut Krathwhol (2002: 215) kemampuan menganaisis (analyze) merupakan kemampuan untuk memilah suatu integritas menjadi unsur-unsur atau bagian-bagian sehingga jelas hierarkinya dan atau susunannya. Sedangkan kemampuan mengevaluasi (evaluate) merupakan kemampuan untuk memberikan penilaian terhadap solusi, gagasan, dan metodologi dengan menggunakan kriteria yang cocok atau standar yang ada untuk memastikan nilai efektifitas atau manfaatnya.Dan kemampuan mencipta (create) merupakan kemampuan memadukan unsurunsur menjadi sesuatu bentuk baru yang utuh dan koheren, atau membuat sesuatu yang orisinil.

Gunawan \& Palupi (2008: 28-29) menjelaskan bahwa menganalisis merupakan memecahkan suatu permasalahan dengan memisahkan tiap-tiap bagian dari permasalahan dan mencari keterkaitan dari tiap-tiap bagian tersebut dan mencari tahu bagaimana keterkaitan 
tersebut dapat menimbulkan permasalahan.Kemampuan menganalisis merupakan jenis kemampuan yang banyak dituntut dari kegiatan pembelajaran dikarenakan dalam kegiatan pembelajaran sebagian besar mengarahkan mahasiswa untuk mampu membedakan fakta dan pendapat, menghasilkan kesimpulan dari suatu informasi pendukung. Menganalisis berkaitan dengan proses kognitif memberi atribut (attributeing) dan mengorganisasikan (organizing). Memberi atribut akan muncul apabila mahasiswa menemukan permasalahan dan kemudian memerlukan kegiatan membangun ulang hal yang menjadi permasalahan. Sedangkan mengorganisasikan menunjukkan identifikasi unsur-unsur hasil komunikasi atau situasi dan mencoba mengenali bagaimana unsur-unsur ini dapat menghasilkan hubungan yang baik.Hal pertama yang harus dilakukan oleh mahasiswa adalah mengidentifikasi unsur yang paling penting dan relevan dengan permasalahan, kemudian melanjutkan dengan membangun hubungan yang sesuai dari informasi yang telah diberikan. Sementara itu, kemampuan evaluasi berkaitan dengan proses kognitif memberikan penilaian berdasarkan kriteria dan standar yang sudah ada. Kegiatan mengevaluasi meliputi mengecek (checking) dan mengkritisi (critiquing).Mengecek mengarah pada kegiatan pengujian hal-hal yang tidak konsisten atau kegagalan dari suatu operasi atau produk.Mengkritisi mengarah pada penilaian suatu produk atau operasi berdasarkan pada kriteria dan standar eksternal.

Senada dengan Gunawan \& Palupi, Gunawan (Agustyaningrum, 2015)mengungkapkan bahwa kemampuan analisis dapat berupa kemampuan memeriksa dan mengurai informasi (memilah sebab dan akibat), mengambil kesimpulan, dan melakukan generalisasi serta menemukan alasan yang mendukungnya. Sedangkan kemampuan evaluasi merupakan kemampuan menyajikan pendapat dan mempertahankannya dengan memberikan pertimbangan tentang informasi, fakta, dan atau keabsahan gagasan berdasarkan kriteria tertentu.

Keterampilan berpikir tingkat tinggi merupakan keterampilan yang dapat dilatihkan.Dalam hal ini peran pendidik adalah sebagai fasilitator yang mendesain kegiatan pembelajaran sekaligus perangkat pembelajaran termasuk bahan ajar agar dapat menjadi tempat bagi siswa untuk mengembangkan keterampilan berfikir tingkat tingginya.Melihat permasalahan yang ada maka penelitian ini difokuskan untuk (1) Menghasilkan produk berupa bahan ajarberbentuk modul sruktur aljabar berbasis pendekatan deduktif yang valid dan praktis: (2) Mengetahui dampak bahan ajar struktur aljabar berbasis pendekatan deduktif dalam meningkatkan HOT skill mahasiswa Program Studi Pendidikan Matematika Universitas Riau Kepulauan (UNRIKA). 


\section{METODOLOGI PENELITIAN}

Penelitian ini merupakan jenis penelitian pengembangan (research and development). Model pengembangan yang digunakan dalam penelitian ini merujuk pada teori pengembangan dari Thiagarajan yaitu model pengembangan 4D yang merupakan kepanjangan dari define, design, development, and dissemination. Dijelaskan oleh Sugiyono (2015: 37-38) bahwa:(1) tahap pendefinisian (Define) merupakan kegiatan untuk untuk menetapkan produk apa yang akan dikembangkan beserta spesifikasinya. Tahap ini merupakan kegiatan analisis kebutuhan yang dilakukan melalui penelitian dan studi literatur.

(2) Tahap perancangan (design) berisi kegiatan untuk membuat rancangan terhadap produk yang telah ditetapkan. Dalam tahap ini, peneliti sudah membuat produk awal (prototype); (3) Thiagarajan (Mulyatiningsih, 2013: 3) membagi tahap pengembangan (development) dalam dua kegiatan yaitu: expert appraisal dan developmental testing.Expert appraisal merupakan teknik untuk memvalidasi atau menilai kelayakan rancangan produk.Dalam kegiatan ini dilakukan evaluasi oleh ahli dalam bidangnya.Developmental testing merupakan kegiatan uji coba rancangan produk pada sasaran subjek yang sesungguhnya.Pada saat uji coba ini dicari data respon, reaksi atau komentar dari sasaran pengguna produk.Hasil uji coba digunakan untuk memperbaiki produk. Setelah produk diperbaiki kemudian diujikan kembali sampai memperoleh hasil yang efektif;(4) tahap diseminasi merupakan kegiatan menyebarluaskan produk yang telah teruji untuk dimanfaatkan orang lain. Pada tahap ini merupakan tahap penggunaan perangkat yang telah dikembangkan pada skala yang lebih luas misalnya di kelas lain atau di perguruan tinggi yang lain.

Agar lebih mudah dipahami, prosedur pengembangan dalam penelitian ini dapat dilihat pada gambar 1 berikut. 


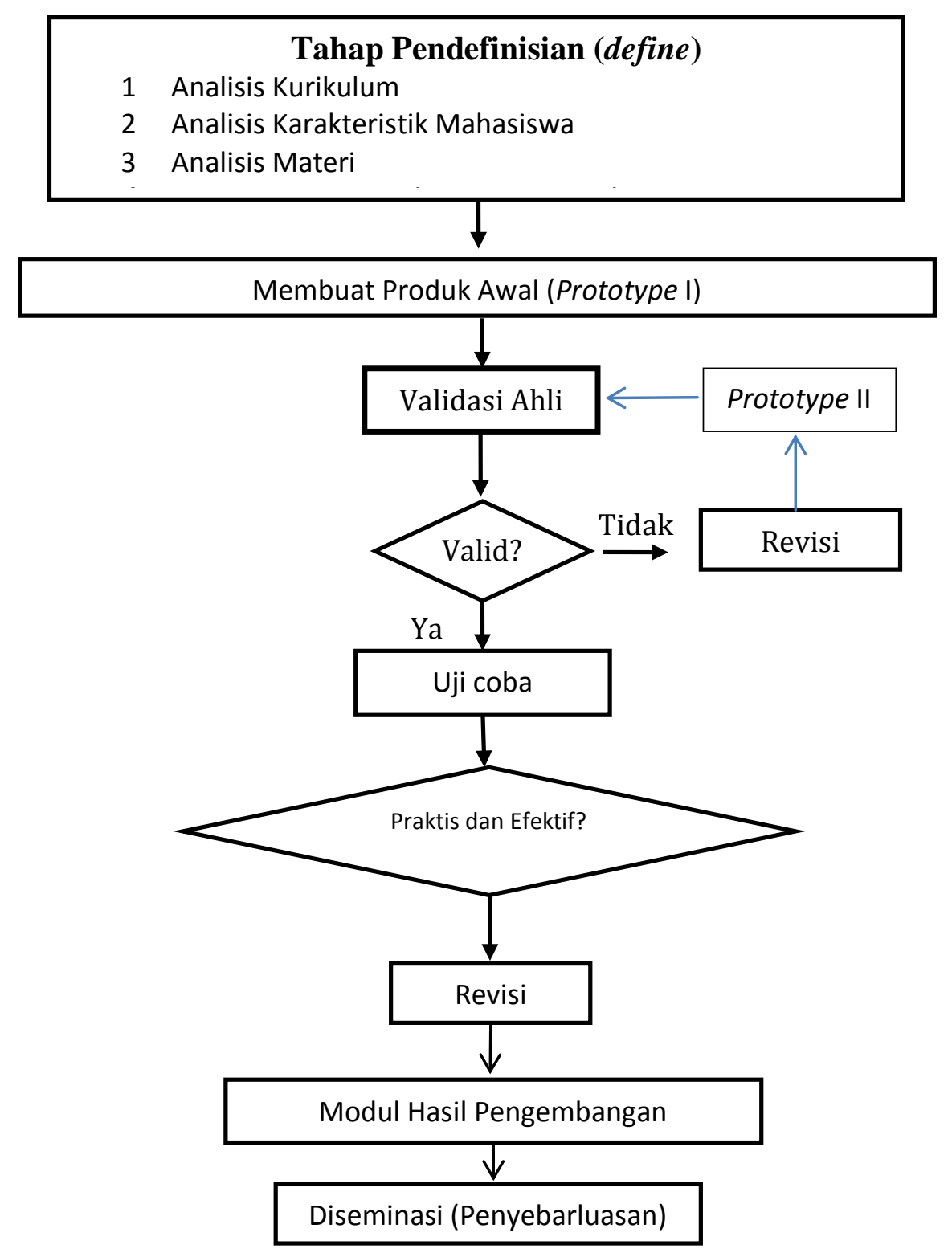

Gambar 1. Prosedur Pengembangan Bahan Ajar (Modul)

Prototipe yang dikembangkan melalui studi literatur diuji validitasnya oleh dua dosen Universitas Mercubuana Yogyakarta sebagai pakar atau ahli.Data validasi terdiri atas data kuantitatif dan kualitatif.Data kuantitatif merupakan skor-skor yang diperoleh dari validator dengan menggunakan skala yang mencakup aspek kevalidan dan kepraktisan modul.Sementara itu, data kualitatif berupa saran, komentar, dan kritik baik secara tertulis maupun lisan.Data validasi baik kuantitatif maupun kualitatif digunakan sebagai bahan 
pertimbangan untuk melakukan revisi demi penyempurnaan modul (prototipe 2).Selain itu, komponen penilaian dari pengembangan ini dapat dilihat pada Tabel 1 berikut.

Tabel 1. Komponen Penilaian Pengembangan Bahan Ajar (Modul) Pembelajaran

\begin{tabular}{|c|c|c|c|}
\hline Aspek yang diukur & Instrument & Data yang diamati & Responden \\
\hline Kevalidan bahan ajar & Lembar validasi & $\begin{array}{l}\text { Kevalidan bahan ajar dari } \\
\text { segi konten, penyajian, } \\
\text { dan Bahasa }\end{array}$ & Validator (ahli) \\
\hline Kepraktisan bahan ajar & Angket & $\begin{array}{l}\text { Respon mahasiswa terkait } \\
\text { kemudahan penggunaan } \\
\text { bahan ajar }\end{array}$ & Mahasiswa \\
\hline Keefektifan bahan ajar & Tes HOT Skill & $\begin{array}{l}\text { Kemampuan } \\
\text { tingkat tinggi }\end{array}$ & Mahasiswa \\
\hline
\end{tabular}

\section{HASIL DAN PEMBAHASAN}

Berdasarkan hasil validasi dari dua validator (ahli), diperoleh persentase skor rata-rata seluruh aspek yaitu aspek kelayakan isi, penyajian, dan kebahasaan adalah 90,77\% dan termasuk kategori sangat baik. Menurut kriteria kevalidan yang telah ditetapkan, maka prototipe bahan ajar berupa modul yang telah dikembangkan dapat dikatakan valid.Hal ini berarti modul layak digunakan dengan memperhatikan saran dan komentar dari validator. Selanjutnya kegiatan ujicoba dilakukan pada mahasiswa program studi pendidikan matematika semester VI A Universitas Riau Kepulauan tahun ajaran 2016/2017. Uji coba produk dilaksanakan selama satu bulan yaitu pada pertengahan bulan Februari-Maret 2017.Selanjutnya mahasiswa diberikan angket untuk mengetahui kepraktisan modul serta diberikan tes untuk mengukur kemampuan berpikir tingkat tingginya sebagai tolok ukur keefektifan modul.

Setelah pelaksanaan ujicoba, mahasiswa diberikan angket untuk menilai kepraktisan modul.Angket terdiri dari 12 pernyataan dengan skala 1-4.Hasil perolehan skor angket disajikan pada tabel 2 berikut.

Tabel 2. Deskripsi Data Skor Angket Respon Mahasiswa

\begin{tabular}{cc}
\hline Deskripsi Data & Skor \\
\hline Rata-rata & 38,2 \\
Simpangan Baku & 3,18 \\
Varians & 10,11 \\
Skor tertinggi & 45 \\
Skor terendah & 33 \\
Skor maximum ideal & 48 \\
Skor minimum ideal & 12 \\
Jumlah responden & 25 \\
\hline
\end{tabular}


Berdasarkan tabel 2, terlihat bahwa rata-rata skor angket adalah 38,2 dari skor maksimum 48. Skor simpangan baku sebesar 3,18 menunjukkan bahwa para responden ratarata memberikan nilai yang tidak jauh berbeda dari nilai rata-rata. Hal ini berarti rata-rata responden memberikan respon yang baik terhadap penggunaan modul. Selanjutnya berdasarkan perhitungan diperoleh tingkat pencapaian kepraktisan modul adalah 79,83\% dan termasuk pada kategori baik. Artinya modul sudah praktis atau mudah untuk digunakan.

Setelah diperoleh modul yang valid dan praktis, maka untuk melihat efektif atau tidaknya bahan ajar berupa modul yang dikembangkan ditinjau dari kemampuan berpikir tingkat tinggi mahasiswa, maka mahasiswa diberikan tes kemampuan berpikir tingkat tinggi yang mengukur kemampuan menganalisis dan kemampuan mengevaluasi.

Sebelum digunakan, soal tes sebelumnya juga dikonsultasikan pada validator yang sama dengan validator untuk ahli materi. Hasil validasi dengan validitas isi, dihitung koefisien validitasnya menggunakan indeks Gregory. Berdasarkan hasil perhitungan diperoleh koefisien validitas sebesar 0,67, sehingga instrumen tes ini validitasnya sedang. Selanjutnya, instrumen tes yang telah valid diberikan kepada subjek penelitian yaitu mahasiswa pendidikan matematika semester VI A (sebagai kelas eksperimen yang menggunakan modul) dan semester VI B (sebagai kelas kontrol yang tidak menggunakan modul). Deskripsi data hasil tes yang diperoleh disajikan pada tabel 3 berikut:

Tabel 3. Deskripsi Data Skor Tes Higher Order Thinking Skill

\begin{tabular}{lll}
\hline \multirow{2}{*}{\multicolumn{1}{c}{ Deskripsi Data }} & \multicolumn{2}{c}{ Kelas } \\
\cline { 2 - 3 } & Eksperimen & Kontrol \\
\hline Rata-rata & 62,46 & 60,53 \\
Simpangan Baku & 11,07 & 10,01 \\
Varians & 122,55 & 100,2 \\
Skor tertinggi & 83,3 & 83,3 \\
Skor terendah & 36,7 & 43,3 \\
Skor maximum ideal & 100 & 100 \\
Skor minimum ideal & 0 & 0 \\
Jumlah responden & 25 & 19 \\
\hline
\end{tabular}

Berdasarkan tabel 3 di atas, terlihat bahwa rata-rata skor tes pada kelas eksperimen sebesar 62,46 dan pada kelas kontrol 60,53 dengan simpangan baku berturut-turut 11,07 dan 10,01. Hasil ini kemudian dianalisis dengan menggunakan uji statistik non parametrik MannWhitney $U$ test dikarenakan asumsi normalitas pada data ini tidak terpenuhi. Hasil uji U Mann-Whitney diperoleh nilai signifikansi (2-tailed) 0,310. Hasil ini lebih besar dari nilai 
taraf signifikansi 0,05 sehingga dapat disimpulkan bahwa tidak terdapat perbedaan yang signifikan antara skor kelas eksperimen dan kontrol.

Selanjutnya berdasarkan distribusi skor juga dapat diketahui bahwa banyaknya mahasiswa yang memperoleh nilai $\geq 60$ pada kelas eksperimen ada sebanyak 17 mahasiswa dari 25 mahasiswa atau sebesar 68\% mahasiswa. Sedangkan pada kelas kontrol terdapat 11 dari 19 mahasiswa yang mengikuti tes atau sebesar 57,89\% mahasiswa yang meperoleh nilai $\geq 60$. Hasil ini cukup memuaskan mengingat sebagian besar mahasiswa merasa bahwa mata kuliah struktur aljabar adalah salah satu mata kuliah yang paling sulit sehingga tidak mudah untuk langsung mendapatkan hasil yang memuaskan.Selanjutnya perbedaan skor yang tidak signifikan antara kelas eksperimen dengan kelas kontrol juga tidak berarti bahwa modul tidak efektif untuk digunakan, hanya penggunaannya saja yang perlu dimaksimalkan lagi.Hal ini analisis praktikalitas penggunaan modul yang menunjukkan hasil bahwa modul praktis untuk digunakan.

Dalam penelitian ini hasil pengembangan dikatakan efektif apabila terdapat perbedaan yang signifikan antara rata-rata hasil tes kelas eksperimen dan kontrol yaitu skor kelas eksperimen lebih tinggi secara signifikan dari kelas kontrol. Berdasarkan analisis secara statistik memang diperoleh hasil perbedaan skor yang tidak signifikan meskipun skor kelas eksperimen lebih tinggi dari skor kelas kontrol dengan selisih sebesar 1,93. Nilai rata-rata ini memang belum mencapai kriteria skor yang baik seperti yang peneliti harapkan. Namun demikian, adanya simpangan baku yang besar juga dapat menjadi salah satu penyebab rendahnya skor rata-rata. Simpangan baku yang besar menandakan terdapat kesenjangan perolehan nilai mahasiswa di mana sebagian mahasiswa mendapat nilai tinggi sementara sebagian lainnya mendapat nilai sangat rendah. Berdasarkan hasil yang diperoleh dapat disimpulkan bahwa modul yang dikembangkan belum cukup efektif ditinjau dari higher order thinking skill mahasiswa.

\section{KESIMPULAN DAN SARAN}

Dari penelitian yang telah dilaksanakan, dapat disimpulkan bahwa:

1. Bahan ajar berupa modul struktur aljabar berbasis pendekatan deduktif yang dihasilkan telah valid dan praktis dengan tingkat kevalidan sebesar 90,77\% (kategori sangat baik) berdasarkan penilaian ahli (validator) dan tingkat kepraktisan sebesar 79,85\% (kategori baik) berdasarkan angket respon mahasiswa. 
2. Dampak bahan ajar berupa modul struktur aljabar berbasis pendekatan deduktif yang dihasilkan belum cukup efektif dalam meningkatkan higher order thinking skill (kemampuan berpikir tingkat tinggi) mahasiswa dengan perolehan skor rata-rata hasil tes kemampuan berpikir tingkat tinggi pada kelas eksperimen sebesar 62,46 dan kelas kontrol 60,53. Dari hasil uji statistik dengan uji U Mann Whitney diperoleh nilai signifikasi 0,31 lebih besar dari taraf signifikan 0,05 sehingga dapat disimpulkan bahwa tidak terdapat perbedaan yang signifikan antara hasil tes kelompok eksperimen dan kontrol.

Berdasarkan perolehan hasil penelitian, maka peneliti dapat menyampaikan beberapa saran sebagai berikut:Bagi dosen pengampu mata kuliah struktur aljabar agar berkenan menggunakan modul ini sebagai bahan tambahan sumber belajar.Bagi peneliti lain dapat mencoba mengembangkan bahan ajar serupa pada materi yang berbeda sesuai dengan kebutuhan. Modul sebaiknya juga diujicobakan pada kelas lain atau universitas lain untuk mengetahui dampak efektifitasnya secara lebih lanjut.Mahasiswa agar dapat menggunakan modul struktur aljabar berbasis pendekatan deduktif ini sebagai alternatif bahan pembelajaran pada perkuliahan struktur aljabar.

\section{REFERENSI}

Agustyaningrum, N. (2015). Mengembangkan Keterampilan Berpikir Tingkat Tinggi dalam Pembelajaran Matematika SMP. Pythagoras: Jurnal Program Studi Pendidikan Matematika, 4(1), 39-46. Retrieved journal.unrika.ac.id/index.php/jurnalphythagoras/article/download/586/449

Chiappetta, Eugene L \& Koballa Jr, Thomas R. (2010). Science Intruction in The Middle and Secondary Schools Developing Fundamental Knowledge and Skills. Boston: Pearson Education Inc.

Gusmania, Y. dan T. P. (2010). Pengembangan Modul Geometri Analitik Bidang Berbasis Contextual Teaching Learning (CTL) untuk Meningkatkan Kompetensi Mahasiswa Universitas Riau Kepulauan (UNRIKA). Dimensi, 4(3), 1-11. Retrieved from http://journal.unrika.ac.id/index.php/jurnaldms/article/view/44/42

Gunawan, Imam.,\& Palupi, Anggraini R. (2008). Taksonomi Bloom - Revisi Ranah Kognitif: Kerangka Landasan Untuk Pembelajaran, Pengajaran, dan Penilaian. https://akhmadsudrajat.files.wordpress.com/2008/01/revisi-taksonomi-bloom.pdf diakses 10 Oktober 2016.

Hurlock, E.B. (1978). Child Development Sixth Edition. London: Mc-Graw-Hill, Inc.

Krathwohl, D.R. (2002). A Revision of Bloom's Taxonomy: An Overview. https://teaching.yale-nus.edu.sg/wp-content/uploads/sites/25/2016/02/A-Revision-ofBlooms-Taxonomy_An-Overview.pdf diakses 10 Oktober 2016

Krulik, S \& Rudnick. (1999). Innovative Tasks to Improve Critical- and Creative-Thinking Skills. Developing Mathematical Reasoning in Grades K-12 , pp. 138-145. idrisharta.blogspot.com/.../higher-order-thinking-skills-in-math.html.diakses Oktober 2011

Mulyatiningsih, $\quad$ Endang. (2013). Pengembangan Model Pembelajaran.http://staff.uny.ac.id/sites/default/files/pengabdian/dra-endang- 
mulyatiningsih-mpd/7cpengembangan-model-pembelajaran.pdf diakases 12 Desember 2016.

Tran Vui (2001). Effective Mathematics Teaching Strategies InspiringProgressive Students: Student-Centered Approach. Penang, Malaysia:Recsam http://fadjarp3g.files.wordpress.com/2007/09/okberpikirtktinggimat_median.pdf diakses 10 Oktober 2011

Sagala, Syaiful. (2010). Konsep dan Makna Pembelajaran.Alfabeta : Bandung.

Sugiyono.(2015). Metode Penelitian \& Pengembangan Research and Development. Bandung: Penerbit Alfabeta

Sukirman.(2005). Pengantar Aljabar Abstrak. Malang: Penerbit Universitas Negeri Malang.

Utari, R. (2017). TAKSONOMI BLOOM Apa dan Bagaimana Menggunakannya?.http://ueu7361.weblog.esaunggul.ac.id/wpcontent/uploads/sites/5928/2017/01/Taksonomi-Bloom.pdf diakses 10 Oktober 2016

Rosnawati, R. (2009). Enam Tahapan Aktivitas dalam Pembelajaran Matematika untuk Mendayagunakan Berpikir Tingkat Tinggi Siswa. In Seminar Nasional dengan tema: "Revitalisasi MIPA dan Pendidikan MIPA dalam rangka Penguasaan Kapasitas Kelembagaan dan Profesionalisme Menuju WCU” pada tanggal 16 Mei 2009 (pp. 112). Yogyakarta. Retrieved from https://www.google.co.id/url?sa=t\&rct=j\&q=\&esrc=s\&source=web\&cd=1\&cad=rja\&ua ct=8\&ved=0ahUKEwilldO4g_LUAhXKO48KHVhlDkQQFggmMAA\&url=http\%3A\% 2F\%2Fstaffnew.uny.ac.id\%2Fupload\%2F132001808\%2Fpenelitian\%2FENAM\%2BTA HAPAN\%2BAKTIVITAS\%2BDALAM\%2BPEMBELAJARAN\%2BMATEMATIKA \%2BUNTUK\%2BMENDAYAGUNAKAN\%2BBERPIKIR\%2BTINGKAT\%2BTINGG I\%2BSISWA.pdf\&usg=AFQjCNEBj6wyW6mFQIGJaTWyx8WAPI85Fw 